\title{
Recycling Nutrient by Integration of Pond Aquaculture and Aquatic Vegetable Cultivation
}

\author{
Ling Tao ${ }^{1,2,3, \text { a } \text {, Jianqiang Zhu }}{ }^{1 *, b}, \mathrm{Gu} \mathrm{Li}^{2 *, \mathrm{c}}$ and Xiaoli $\mathrm{Li}^{2, \mathrm{~d}}$ \\ ${ }^{1}$ Engineering and Research Center on Ecology of Wetland and Agricultural Use, Ministry of \\ Education, Yangtze University, Jingzhou 434025, China \\ ${ }^{2}$ Yangtze River Fisheries Research Institute, Chinese Academy of Fishery Sciences, Wuhan \\ 430223, China \\ ${ }^{3}$ Freshwater Aquaculture Collaborative Innovation Center of Hubei Province, Wuhan 430070, China \\ a taolingcjs@yfi.ac.cn, ${ }^{\mathrm{b}}$ zyjb@sina.com, ${ }^{\mathrm{c}}$ ligu667@yahoo.com, ${ }^{\mathrm{d}} \mathrm{Ix|} @$ yfi.ac.cn \\ ( ${ }^{*}$ Co-corresponding author)
}

Keywords: Pond aquaculture; aquatic vegetable; wastewater purification; Biolog Eco-plate; Microbial diversity

Abstract: This experiment was designed to assess the recovery of nutrient from aquaculture pond effluent by lotus (Nelumbo nucifera) and cane shoot ( Zizania latifolia) cultivation field based on the pit-testing experiment.The results showed that under retention water management, the recycling rate of cane shoot and lotus root test pit on TN, TP and $\mathrm{COD}_{\mathrm{Mn}}$ in the aquaculture wastewater was increased with the retention time, in which the difference of TN and TP was significant when the retention time was longer than $24 \mathrm{~h}$. Under surface flow operation, the removal efficiency on $\mathrm{NO}_{2}{ }^{-} \mathrm{N}$, $\mathrm{NH}_{4}{ }^{+}-\mathrm{N}, \mathrm{TN}, \mathrm{TP}$ and $\mathrm{COD}_{\mathrm{Mn}}$ from pond wastewater were $11.30 \% \sim 26.27 \%, 8.30 \% \sim 26.60 \%$, $1.87 \% \sim 20.60 \%, 11.0 \% \sim 19.70 \%$ and $23.00 \% \sim 30.65 \%$ with the influent flow rate of $0.08 \mathrm{~m}^{3} / \mathrm{h}$ and $0.13 \mathrm{~m}^{3} / \mathrm{h}$. The microbial diversity indices of effluent from both the two vegetable test pits were significantly higher than those of influent water under the retention water management and significantly lower than those of influent water under surface flow operation. Comprehensively considering, retention management is more preferable and retention time should be longer than 24 $\mathrm{h}$.The present experiment confirmed that ex-situ treatment of aquaculture wastewater by lotus and water bamboo cultivation field is feasible and effective in recycling nutrients in the aquaculture wastewater and reducing nutrient pollution discharge. The integration of pond aquaculture and aquatic vegetable production are environmentally friendly and more research is needed to provide efficient management strategies during the practical integration practice.

\section{Introduction}

Fishponds accounted for $42.7 \%$ of the inland aquaculture area in China and provided $69.3 \%$ of the total freshwater aquaculture production[1]. As the most important aquaculture mode in China, fishpond production guarantees the supply of aquatic products for modern society and provides the most efficient means of production for high quality and inexpensive animal protein in China. However, during the large scale intensification in pond aquaculture in China for the recent two decades, large quantities of baits, fertilizers and drugs have been poured in the pond, leading to the discharge of over 300 million cubic meters aquaculture wastewater and exacerbating the eutrophication and pollution of streams, rivers and lakes[2]. Therefore, the problem that needs urgent solution currently is how to maintain the environmental suitability while improving the output facing the more and more stringent nutrient discharge limits of freshwater waste [3]. A number of methods have been investigated to mitigate pollution from pond effluent. Constructed wetland was used for treatment of pond effluent with significant results $[4,5]$. Using grass turf to filter pollutants from channel catfish pond effluent, however, was less effective[6]. Paddy field was confirmed the high recovery of the nutrient from pond effluent[7]. From the economic aspects of treating effluent from channel catfish ponds, Kouka and Engle (1996) concluded that use of wastewater for crop irrigation was most cost-effective[8]. Aquaculture wastes are valuable nutrient resources and can be reused 
through integration of aquaculture-aquaculture and aquaculture-agriculture systems. Furthermore, pond aquaculture and aquatic vegetable cultivation in lowland areas in southern plain lake regions of Yangtze River Basin are relatively common and it is feasible to integrate the aquatic vegetable cultivation with pond aquaculture.

In this study, a pit-testing experiment was conducted using pond effluent to irrigate aquatic vegetable to study the purification and nutrient recycling effect of aquatic vegetable cultivation field on aquaculture effluent and the optimum and practical operational requirements during the integration, ultimately to provide the efficient management strategies in minimizing waste load from freshwater aquaculture pond effluent.

\section{Materials and Methods}

Experiment Design. The experiment site is located in Jingzhou city $\left(30^{\circ} 16^{\prime} \mathrm{N}, 112^{\circ} 18^{\prime} \mathrm{E}\right)$, Hubei Province, China (central China, typical subtropical climate). The experiment was conducted in 6 test pits $(\mathrm{L} \times \mathrm{W} \times \mathrm{H}=1.5 \mathrm{~m} \times 2.0 \mathrm{~m} \times 1.2 \mathrm{~m})$ with 3 replicates for the two aquatic vegetable lotus (Nelumbo nucifera) and cane shoot ( Zizania latifolia), each pit was equipped with relatively independent water supply and drainage devices, and $40 \mathrm{~cm}$ thick sediment was embedded in the test pits. According to the farmers' normal practice, the lotus planting density was $0.5 \mathrm{~m}$ of row pitch and $0.5 \mathrm{~m}$ of plant spacing. The cane shoot planting density was $0.3 \mathrm{~m}$ of row density and $0.3 \mathrm{~m}$ of the plant spacing. When the test was conducted, the aquaculture wastewater in one adjacent intensive aquaculture pond was pumped to the test pits. As water quality in aquaculture pond is usually inclined to deteriorate during the middle and later period of culture that the deteriorated water was exchanged and released to the receiving water, this experiment was conducted from August to September, 2013.

Physico-chemical and Microbial Analysis. To study the purification effect of the aquatic cultivation field for aquaculture wastewater under water retention management, the pond wastewater was pumped into the test pits keeping the $50 \mathrm{~cm}$ thickness of the water layer and retained for $0 \mathrm{~h}, 3 \mathrm{~h}$, $9 \mathrm{~h}, 24 \mathrm{~h}, 33 \mathrm{~h}$ and $57 \mathrm{~h}$ respectively. The influent and effluent water at each retention time was collected using plastic bottles and brought back to the laboratory for physico-chemical analysis. According to the pre-experiment, the water samples of influent and the effluent after $24 \mathrm{~h}$ retention were collected in sterile glass bottles $(500 \mathrm{ml})$ for microbial analysis. To study the purification effect under surface flow management, the rate of inflow was adjusted so that the aquaculture wastewater was slowly flowing on the surface of sediment in the test pits. The influent and effluent water samples were collected at the two surface flow rates of $0.08 \mathrm{~m}^{3} / \mathrm{h}$ and $0.13 \mathrm{~m}^{3} / \mathrm{h}$ (the hydraulic retention time were $4.8 \mathrm{~h}$ and $7.7 \mathrm{~h}$ respectively) and were brought back to the laboratory for analysis immediately. The water samples of influent and the effluent at surface flow rates of $0.08 \mathrm{~m}^{3} / \mathrm{h}$ were collected in sterile glass bottles $(500 \mathrm{ml})$ for microbial analysis.

The ammonia nitrogen $\left(\mathrm{NH}_{4}{ }^{+}-\mathrm{N}\right)$, nitrite nitrogen $\left(\mathrm{NO}_{2}{ }^{-}-\mathrm{N}\right)$, total nitrogen $(\mathrm{TN})$, total phosphorus (TP), and Chemical Oxygen Demand $\left(\mathrm{COD}_{\mathrm{Mn}}\right)$ were analyzed according to the reference[9]. BIOLOG Eco-plates (BIOLOG Inc., Hayward CA., USA) consisting of 96 wells, with 31 different carbon sources and a blank in triplicate, were used to determine the community-level physiological profiling of microbial populations in the water. Each well of the plate was inoculated with $150 \mu \mathrm{L}$ of water sample and the plates were incubated in the dark at $25^{\circ} \mathrm{C}$. Color development in the plates was measured every 24 hours at $590 \mathrm{~nm}$ using a BIOLOG reader until the end of incubation at $168 \mathrm{~h}$.

Data Analysis. The functional diversity of the microbial communities was characterized using the raw absorbance values for each well blanked against the control well. Negative absorbance values were set to zero according to Garland [10]. The diversity indices, including the Shannon index $\left(\mathrm{H}^{\prime}\right)$, Simpson index (D), Shannon evenness index (Eh), McIntosh index (U), and McIntosh evenness index $(\mathrm{Eu})$, were used to assess water microbial functional diversity [11].

Statistical analyses were performed using SPSS 18.0 (SPSS Inc., Chicago, IL, USA). Differences between means were compared using one-way analysis of variance (ANOVA). Means were considered to be significantly different at a $95 \%$ confidence level. The values in the figures and tables corresponded to the mean \pm standard deviation (SD). 


\section{Results and Analysis}

Purification Effect under Retention Water Management. The experimental results are listed in Table1 $(\mathrm{a}, \mathrm{b})$, as can be seen that the concentrations of $\mathrm{NO}_{2}{ }^{-} \mathrm{N}, \mathrm{NH}_{4}{ }^{+} \mathrm{N}, \mathrm{TN}, \mathrm{TP}$ and $\mathrm{COD}_{\mathrm{Mn}}$ in the pond wastewater displayed a decreasing tendency with the increase of retention time. After retention in cane shoot test pits, the $\mathrm{NO}_{2}^{-}-\mathrm{N}$ concentration significantly dropped after $24 \mathrm{~h}$ retention. The $\mathrm{NH}_{4}{ }^{+}-\mathrm{N}$ concentration significantly dropped after $3 \mathrm{~h}$ retention. The TN and $\mathrm{COD}_{\mathrm{Mn}}$ concentration significantly dropped after $33 \mathrm{~h}$ retention, and the TN concentration was $\leq 1.0 \mathrm{mg} / \mathrm{L}$, satisfying the class II water standard specified in Surface Water Environmental Quality Standard (GB3838-2002) after $57 \mathrm{~h}$ retention. After retention in lotus root test pits, the $\mathrm{NO}_{2}^{-}-\mathrm{N}$ and $\mathrm{TN}$ concentrations of the pond wastewater significantly decreased after $33 \mathrm{~h}$ retention, and the $\mathrm{COD}_{\mathrm{Mn}}$ concentrations significant decreased after $57 \mathrm{~h}$ retention while the TP concentrations did not display a significant difference after $57 \mathrm{~h}$ retention comparing to the concentrations in influent; The $\mathrm{NH}_{4}{ }^{+}-\mathrm{N}$ concentration significantly decreased after $3 \mathrm{~h}$ retention and subsequently increased; after $57 \mathrm{~h}$ retention, the concentration significantly dropped again. Removal rate of aquatic vegetable cultivation field on aquaculture wastewater along with retention time are shown in Figure 1. It was found that the removal rate of cane shoot test pits on $\mathrm{TN}$ was significantly higher than that of lotus root test pits.

Table 1(a) Concentrations of $\mathrm{NO}_{2}^{-}-\mathrm{N}, \mathrm{NH}_{4}{ }^{+}-\mathrm{N}, \mathrm{TN}$ at different retention time

\begin{tabular}{|c|c|c|c|c|c|c|}
\hline \multirow{2}{*}{$\begin{array}{l}\text { Retention } \\
\text { time (h) }\end{array}$} & \multicolumn{2}{|c|}{$\mathrm{NO}_{2} \mathrm{~N}\left(\mathrm{mg} \cdot \mathrm{L}^{-1}\right)$} & \multicolumn{2}{|c|}{$\mathrm{NH}_{4}^{+}-\mathrm{N}\left(\mathrm{mg} \cdot \mathrm{L}^{-1}\right)$} & \multicolumn{2}{|c|}{$\mathrm{TN}\left(\mathrm{mg} \cdot \mathrm{L}^{-1}\right)$} \\
\hline & Cane shoot & Lotus root & Cane shoot & Lotus root & Cane shoot & Lotus root \\
\hline 0 & $0.175 \pm 0.005^{\mathrm{a}}$ & $0.175 \pm 0.009^{\mathrm{a}}$ & $1.61 \pm 0.01^{\mathrm{a}}$ & $1.61 \pm 0.01^{\mathrm{a}}$ & $2.76 \pm 0.02^{\mathrm{a}}$ & $2.76 \pm 0.05^{\mathrm{ab}}$ \\
\hline 3 & $0.176 \pm 0.014^{\mathrm{a}}$ & $0.189 \pm 0.017^{\mathrm{a}}$ & $1.06 \pm 0.08^{\mathrm{b}}$ & $1.29 \pm 0.14^{\mathrm{b}}$ & $2.62 \pm 0.29^{\mathrm{a}}$ & $3.02 \pm 0.08^{\mathrm{a}}$ \\
\hline 9 & $0.145 \pm 0.044^{\mathrm{a}}$ & $0.16 \pm 0.040^{\mathrm{a}}$ & $0.83 \pm 1.61^{\mathrm{c}}$ & $1.61 \pm 0.09^{\mathrm{a}}$ & $2.36 \pm 0.25^{\mathrm{a}}$ & $3.01 \pm 0.22^{\mathrm{a}}$ \\
\hline 24 & $0.063 \pm 0.046^{\mathrm{b}}$ & $0.177 \pm 0.102^{\mathrm{a}}$ & $0.82 \pm 0.40^{\mathrm{c}}$ & $1.55 \pm 0.18^{\mathrm{a}}$ & $1.73 \pm 0.39^{\mathrm{a}}$ & $2.63 \pm 0.14^{\mathrm{bc}}$ \\
\hline 33 & $0.045 \pm 0.066^{\mathrm{b}}$ & $0.118 \pm 0.041^{b}$ & $0.66 \pm 0.16^{\mathrm{c}}$ & $1.62 \pm 0.3^{\mathrm{a}}$ & $1.28 \pm 0.36^{\mathrm{b}}$ & $2.32 \pm 0.18^{\mathrm{cd}}$ \\
\hline 57 & $0.027 \pm 0.037^{\mathrm{b}}$ & $0.099 \pm 0.031^{\mathrm{b}}$ & $0.65 \pm 0.11^{\mathrm{c}}$ & $0.31 \pm 0.33^{\mathrm{c}}$ & $0.83 \pm 0.16^{\mathrm{b}}$ & $2.02 \pm 0.27^{\mathrm{d}}$ \\
\hline
\end{tabular}

Table 1(b) Concentrations of TP and $\mathrm{COD}_{\mathrm{Mn}}$ at different retention time

\begin{tabular}{cllll}
\hline \multirow{2}{*}{$\begin{array}{c}\text { Retention time } \\
\text { (h) }\end{array}$} & \multicolumn{2}{c}{$\mathrm{TP}\left(\mathrm{mg} . \mathrm{L}^{-1}\right)$} & \multicolumn{2}{c}{$\mathrm{COD}_{\mathrm{Mn}}\left(\mathrm{mg} . \mathrm{L}^{-1}\right)$} \\
\cline { 2 - 5 } & Cane shoot & Lotus root & Cane shoot & Lotus root \\
\hline 0 & $0.48 \pm 0.04^{\mathrm{a}}$ & $0.48 \pm 0.01^{\mathrm{a}}$ & $17.11 \pm 0.40^{\mathrm{a}}$ & $17.11 \pm 0.1 \mathrm{o}^{\mathrm{a}}$ \\
3 & $0.35 \pm 0.04^{\mathrm{a}}$ & $0.41 \pm 0.01^{\mathrm{a}}$ & $16.41 \pm 9.84^{\mathrm{a}}$ & $16.92 \pm 9.44^{\mathrm{a}}$ \\
9 & $0.31 \pm 0.01^{\mathrm{b}}$ & $0.40 \pm 0.00^{\mathrm{a}}$ & $13.95 \pm 4.08^{\mathrm{a}}$ & $10.80 \pm 2.65^{\mathrm{a}}$ \\
24 & $0.33 \pm 0.07^{\mathrm{b}}$ & $0.40 \pm 0.01^{\mathrm{a}}$ & $17.03 \pm 9.22^{\mathrm{a}}$ & $11.94 \pm 1.75^{\mathrm{a}}$ \\
33 & $0.32 \pm 0.08^{\mathrm{b}}$ & $0.42 \pm 0.02^{\mathrm{a}}$ & $10.92 \pm 1.46^{\mathrm{b}}$ & $14.84 \pm 3.77^{\mathrm{a}}$ \\
57 & $0.32 \pm 0.08^{\mathrm{b}}$ & $0.41 \pm 0.07^{\mathrm{a}}$ & $10.95 \pm 5.81^{\mathrm{b}}$ & $9.856 \pm 2.88^{\mathrm{b}}$ \\
\hline
\end{tabular}

Purification Effect Under Different Surface Flow Rate. From Table 2, it can be concluded that, the removal rates of the two plant test pits on $\mathrm{NO}_{2}^{-}-\mathrm{N}, \mathrm{NH}_{4}{ }^{+}-\mathrm{N}, \mathrm{TN}, \mathrm{TP}$ and $\mathrm{COD}_{\mathrm{Mn}}$ were $11.30 \% \sim 26.27 \%, 8.30 \% \sim 26.60 \%, 1.87 \% \sim 20.60 \%, 11.0 \% \sim 19.70 \%$ and $23.00 \% \sim 30.65 \%$. The removal rate of cane shoot test pits on $\mathrm{NH}_{4}{ }^{+}-\mathrm{N}$ was significantly higher than that the lotus root. In addition, the removal rate of lotus root test pits on $\mathrm{NH}_{4}{ }^{+}-\mathrm{N}$ significantly increased under the condition of high flow rate, opposite trend was found in the cane shoot test pits and lotus root test pits $(P<$ $0.05)$.

Changes of the microbial diversity. BIOLOG Eco-plate technology was employed to investigate the changes of microbial metabolic diversity of aquaculture wastewater after purified in the lotus root and cane shoot planting test pits. From Table 3, it can be seen that all the microbial diversity indices of effluent from lotus root and cane shoot test pits were significantly higher than those of influent water under the retention water management and significantly decreased than those of influent water $(P<0.05)$. However, there was no significant difference between lotus root and cane shoot test pits under the same mode of water management $(P>0.05)$. 

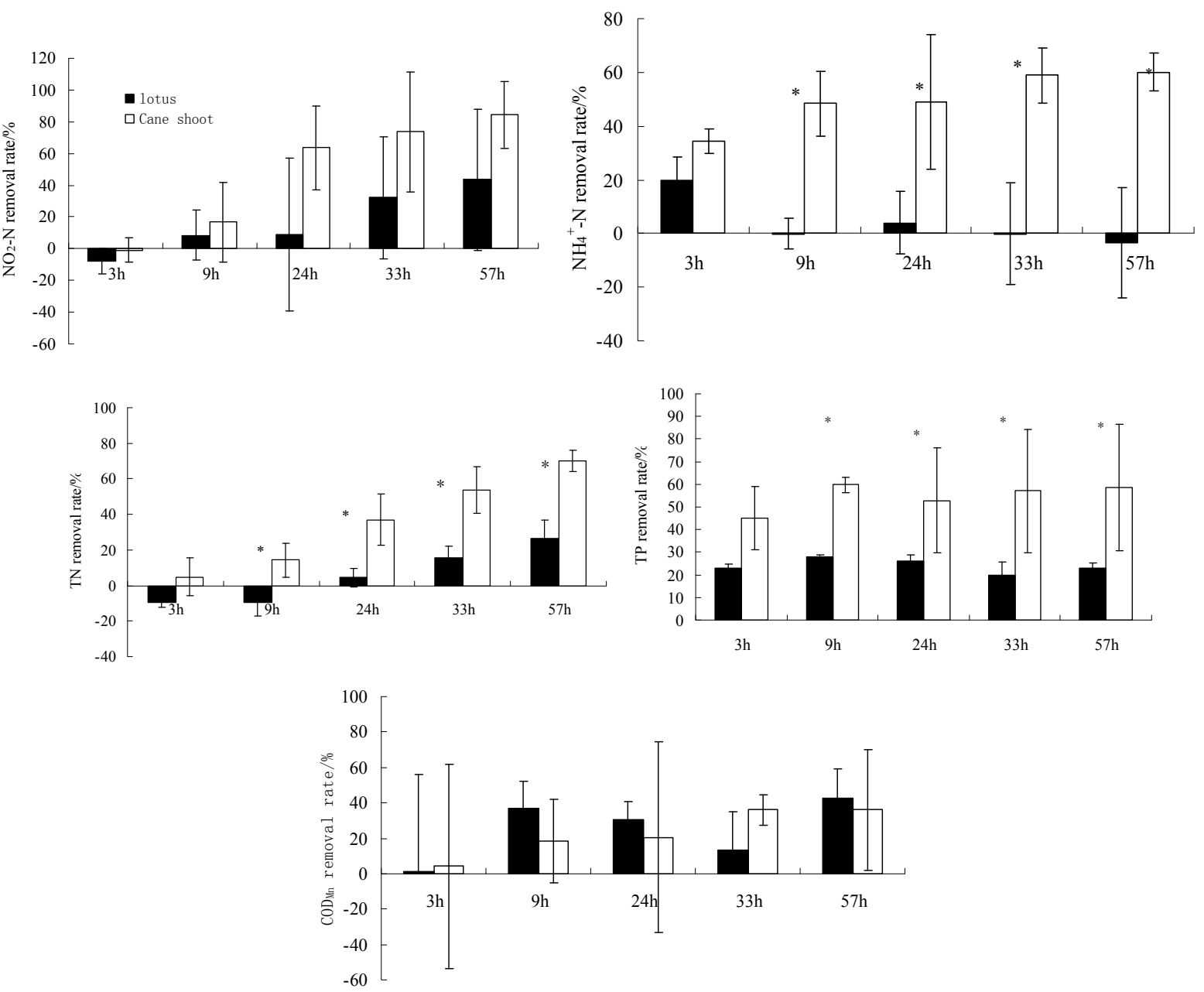

Fig. 1 Removal rate of $\mathrm{NO}_{2}{ }^{-}-\mathrm{N}, \mathrm{NH}_{4}{ }^{+}-\mathrm{N}, \mathrm{TN}, \mathrm{TP}$ and $\mathrm{COD}_{\mathrm{Mn}}$ from aquaculture wastewater along with retention time

Table 2 Purification effect on aquaculture wastewater under different surface flow rate.

\begin{tabular}{clrcccc}
\hline $\begin{array}{c}\text { Flow rate } \\
\left(\mathrm{m}^{3} \cdot \mathrm{h}^{-1}\right)\end{array}$ & Index & $\begin{array}{c}\text { Influent } \\
\text { water } \\
\left(\mathrm{mg} . \mathrm{L}^{-1}\right)\end{array}$ & $\begin{array}{c}\text { Lotus root } \\
\text { effluent water } \\
\left(\mathrm{mg} . \mathrm{L}^{-1}\right)\end{array}$ & $\begin{array}{c}\text { Lotus root } \\
\text { removal rate } \\
(\%)\end{array}$ & $\begin{array}{c}\text { Cane shoot } \\
\text { effluent water } \\
\left(\mathrm{mg} . \mathrm{L}^{-1}\right)\end{array}$ & $\begin{array}{c}\text { Cane shoot } \\
\text { removal rate } \\
(\%)\end{array}$ \\
\hline 0.08 & $\mathrm{NO}_{2}{ }^{-}-\mathrm{N}$ & $0.28 \pm 0.11$ & $0.25 \pm 0.04$ & $12.20 \pm 9.10^{\mathrm{aA}}$ & $0.26 \pm 0.06$ & $11.30 \pm 10.60^{\mathrm{aA}}$ \\
0.13 & $\mathrm{NO}_{2}{ }^{-}-\mathrm{N}$ & $0.25 \pm 0.00$ & $0.20 \pm 0.03$ & $26.27 \pm 26.62^{\mathrm{aA}}$ & $0.21 \pm 0.03$ & $17.97 \pm 41.11^{\mathrm{aA}}$ \\
0.08 & $\mathrm{NH}_{4}{ }^{+}-\mathrm{N}$ & $1.77 \pm 0.23$ & $1.61 \pm 0.20$ & $8.3 \pm 10.61^{\mathrm{bB}}$ & $1.30 \pm 0.16$ & $26.6 \pm 9.73^{\mathrm{aA}}$ \\
0.13 & $\mathrm{NH}_{4}{ }^{+}-\mathrm{N}$ & $1.64 \pm 0.20$ & $1.37 \pm 0.13$ & $23.89 \pm 15.84^{\mathrm{aA}}$ & $1.39 \pm 0.26$ & $22.08 \pm 23.58^{\mathrm{aA}}$ \\
0.08 & $\mathrm{TN}$ & $3.94 \pm 0.40$ & $3.31 \pm 0.20$ & $16.11 \pm 4.88^{\mathrm{aA}}$ & $2.87 \pm 0.21$ & $20.6 \pm 11.3^{\mathrm{aA}}$ \\
0.13 & $\mathrm{TN}$ & $4.37 \pm 0.14$ & $3.64 \pm 0.10$ & $1.87 \pm 10.54^{\mathrm{aB}}$ & $3.54 \pm 0.26$ & $8.31 \pm 9.50^{\mathrm{aB}}$ \\
0.08 & $\mathrm{TP}$ & $0.37 \pm 0.03$ & $0.32 \pm 0.06$ & $13.5 \pm 5.3^{\mathrm{aA}}$ & $0.33 \pm 0.02$ & $11.0 \pm 6.5^{\mathrm{aA}}$ \\
0.13 & $\mathrm{TP}$ & $0.35 \pm 0.03$ & $0.32 \pm 0.01$ & $19.7 \pm 0.80^{\mathrm{aA}}$ & $0.31 \pm 0.01$ & $17.4 \pm 1.2^{\mathrm{aA}}$ \\
0.08 & $\mathrm{COD}$ & $22.29 \pm 6.2$ & $14.85 \pm 4.77$ & $30.65 \pm 21.4^{\mathrm{aA}}$ & $14.16 \pm 3.53$ & $30.0 \pm 17.1^{\mathrm{aA}}$ \\
0.13 & $\mathrm{COD}_{\mathrm{Mn}}$ & $20.62 \pm 3.7$ & $13.74 \pm 2.18$ & $23.00 \pm 14.48^{\mathrm{aA}}$ & $13.41 \pm 3.32$ & $25.99 \pm 14.42^{\mathrm{aA}}$ \\
\hline
\end{tabular}

Remark: Mean values with different superscript letters (a and $b$ ) in the same row for each parameter were significantly different. Mean values with different superscript letters (A and B) in the same collumn for each surface flow rate were significantly different $(P<0.05)$.

Table 3 Microbial diversity indices in the influent and effluent under different water management 


\begin{tabular}{llccccc}
\hline $\begin{array}{c}\text { water } \\
\text { flow } \\
\text { type }\end{array}$ & \multicolumn{1}{c}{ Category } & $\begin{array}{c}\text { Shannon } \\
\text { index (H') }\end{array}$ & $\begin{array}{c}\text { Shannon } \\
\text { evenness } \\
\text { index (Eh) }\end{array}$ & $\begin{array}{c}\text { Simpson } \\
\text { index (D) }\end{array}$ & $\begin{array}{c}\text { McIntosh } \\
\text { index (U) }\end{array}$ & $\begin{array}{c}\text { McIntosh } \\
\text { evenness } \\
\text { index (Eu) }\end{array}$ \\
\hline retention & Influent & $3.211 \pm 0.021^{\mathrm{a}}$ & $0.950 \pm 0.000^{\mathrm{a}}$ & $0.956 \pm 0.002^{\mathrm{a}}$ & $4.502 \pm 0.053^{\mathrm{a}}$ & $0.971 \pm 0.001^{\mathrm{a}}$ \\
& Effluent of & $3.327 \pm 0.010$ & $0.972 \pm 0.005$ & $0.962 \pm 0.001$ & $5.931 \pm 0.158^{\mathrm{b}}$ & $0.983 \pm 0.003$ \\
& Effluent of cane & $3.309 \pm 0.010$ & $0.964 \pm 0.003$ & $0.961 \pm 0.001$ & $5.768 \pm 0.059^{\mathrm{b}}$ & $0.981 \pm 0.001$ \\
surface & $\begin{array}{l}\text { Influent } \\
\end{array}$ & $3.192 \pm 0.048^{\mathrm{a}}$ & $0.948 \pm 0.010^{\mathrm{a}}$ & $0.955 \pm 0.005^{\mathrm{a}}$ & $4.157 \pm 0.290^{\mathrm{a}}$ & $0.967 \pm 0.006^{\mathrm{a}}$ \\
& Effluent of & $2.933 \pm 0.019$ & $0.854 \pm 0.006$ & $0.935 \pm 0.003$ & $3.808 \pm 0.061^{\mathrm{a}}$ & $0.908 \pm 0.005$ \\
& Effluent of cane & $2.802 \pm 0.065$ & $0.816 \pm 0.019$ & $0.918 \pm 0.009$ & $2.713 \pm 0.217^{\mathrm{b}}$ & $0.870 \pm 0.011^{\mathrm{c}}$ \\
\hline
\end{tabular}

Remark: Mean values with different superscript letters ( $a$ and $b$ ) in the same column for each index under the same water management were significantly different $(P<0.05)$

\section{Discussion}

Effluent from aquaculture ponds was an important point source of pollution. Wastewater without treatment, if continuously discharged into the aquatic environment, could result in remarkable elevation of the total organic matter contents and cause considerable economy lost. As specific regulations and standards for developing environmental friendly aquaculture has been shaped, countermeasures should be taken to safeguard the environment for sustainable production of aquatic products. Cultivating aquatic plants in fish pond can effectively reduce the pollution in aquatic aquaculture $[12,13]$. Field that was cultivated lotus root was applied in processing domestic sewage [14]. The integration of aquaculture and loach and mud eel could improve economic benefits [15]. The waterlogged lowland in northern Jiaxing of Zhejiang Province in China were transformed into paddies with integration of pond aquaculture and aquatic economic crops such as lotus root, Trapa acornis Nakai and cane shoot which were locally suitable. Yang et al. (2002) demonstrated the effectiveness of nutrient removal from old pond mud by lotus and the feasibility of rotation and co-culture of lotus and Nile tilapia[16]. Different from the above-mentioned study in which nutrients were recycled effectively within ponds by the aquatic vegetable, the ectopic employing of adjacent aquatic vegetable cultivation field does not involve planting inside the pond, thus not affecting the operation of pond aquaculture.

Under the retention operation, the recycling rate of cane shoot and lotus root cultivation test pits on $\mathrm{TN}, \mathrm{TP}$ and $\mathrm{COD}_{\mathrm{Mn}}$ in aquaculture wastewater was increased with the retention course, in which the difference of TN, TP was significant when the retention time was longer than $24 \mathrm{~h}$, indicating that the pollutant load were one of the main dependent factors for $\mathrm{N}$ and $\mathrm{P}$ removal. Under the surface flow operation, the removal rates of the two test pits on $\mathrm{NO}_{2}{ }^{-} \mathrm{N}, \mathrm{NH}_{4}{ }^{+} \mathrm{N}, \mathrm{TN}, \mathrm{TP}$ and $\mathrm{COD}_{\mathrm{Mn}}$ were $11.30 \% \sim 26.27 \%, 8.30 \% \sim 26.60 \%, 1.87 \% \sim 20.60 \%, 11.00 \% \sim 19.70 \%$ and $23.00 \% \sim 30.65 \%$ with short retention time of $4.8 \mathrm{~h}$ and $7.7 \mathrm{~h}$. The removal mechanisms of $\mathrm{N}$ and $\mathrm{P}$ from wastewater by the aquatic vegetable cultivation field may be mainly through the sediment adsorption, iron exchange, and plant uptake .The particulate $\mathrm{N}$ and $\mathrm{P}$, which is the highest $\mathrm{N}$ and $\mathrm{P}$ fraction in aquaculture effluent, will detention and decompose as long as enough detention time. These results indicated that both the lotus root and cane shoot cultivation field can uptake and remove the nutrient from the aquaculture pond effluent. The microbial diversity indices of effluent from both the two vegetable test pits were significantly higher than those of influent water under the retention water management and significantly lower than those of influent water. This could possibly be due to the fact that the residence time was not long enough for the growth of microbial communities during surface flow water management. Therefore, detention water management is more preferable when employing aquatic vegetable cultivation field to purify the pond aquaculture wastewater for its prevention of the decrease of microbial diversity in the surrounding water environment and water reuse feasibility for pond aquaculture. Except for the removal efficiency, comprehensively considering the seepage and evaporation of the cultivation field and the wastewater treating load, optimal detention time should be longer than $24 \mathrm{~h}$. 
The present study demonstrated that nutrient from aquaculture pond effluent could be reused by both the lotus root and cane shoot cultivation field. Therefore, in the middle and lower reaches of Yangtze River and the southern plain lake regions where aquatic economic vegetable cultivation field distribute adjacent to the aquaculture pond, the pond aquaculture wastewater can be retained in the nearby vegetable cultivation field before discharging to the environment .This kind of integration could contribute to the reduction of inorganic nutrient discharge into waters, decreasing the potential for outbreaks of devastating and costly hypertrophic events. The $\mathrm{N}$ and $\mathrm{P}$ could be captured and converted into the production of saleable vegetable while minimizing the use of fertilizer. We only studied the nutrient removal efficiency of cultivation field during August to September when the pond exchange wastewater is releasing. We assume that it is also feasible during harvest season usually in October and November although the aquatic plant is in the wilting stage with probably less effective purification. Alternatively, after draining the surplus sludge detained in the pond can be pumped into the cultivation field to the aquatic vegetable when treating the sediment between crop when mandatory effluent and sludge control measures were to be enforced. Moreover, this integration was relatively easy and inexpensive, and the vegetable cultivation field treated effluent could even be pumped back into ponds and be reused for fish production.

\section{Conclusions}

Under the retention operation, the recycling rate of cane shoot and lotus root on TN, TP and $\mathrm{COD}_{\mathrm{Mn}}$ in aquaculture wastewater was increased with the retention course in which the difference of TN and $\mathrm{TP}$ was significant when the retention time was longer than $24 \mathrm{~h}$. Under surface flow operation, the removal efficiency of vegetable cultivated field on $\mathrm{NO}_{2}{ }^{-}-\mathrm{N}, \mathrm{NH}_{4}{ }^{+}-\mathrm{N}, \mathrm{TN}, \mathrm{TP}$ and $\mathrm{COD}_{\mathrm{M}}$ from pond wastewater were $11.30 \% \sim 26.27 \%, \quad 8.30 \% \sim 26.60 \%, \quad 1.87 \% \sim 20.60 \%, \quad 11.0 \% \sim 19.70 \%$ and $23.00 \% \sim 30.65 \%$ respectively with the influent flow rate of $0.08 \mathrm{~m}^{3} / \mathrm{h}$ and $0.13 \mathrm{~m}^{3} / \mathrm{h}$. The microbial diversity indices of effluent from both the two vegetable test pits were significantly higher than those of influent water under the retention water management and significantly lower than those of influent water. Comprehensively considering, detention water management is more preferable and detention time should be more than $24 \mathrm{~h}$.

The nutrient from aquaculture pond effluent could be reused by both the lotus root and cane shoot cultivation field thus the pond aquaculture and aquatic vegetable production can be integrated to mitigate pollution from pond effluent to receiving waters meanwhile maximize the use of surplus materials in the pond wastewater. More research including economic development is needed to optimize a suitable and efficient strategy for the integration during the practical application.

\section{Acknowledgements}

This work was financially supported by the Special Fund for Agro-scientific Research in the Public Interest (201203083), National Key Technology Research and Development Program of the Ministry of Science and Technology of China (2012BAD25B), earmarked fund for Modern Agro-industry Technology Research System (CARS-46), and the Science and Technology Support Program of Hubei Province (2014BCB038).

\section{References}

[1] The Fishery Bureau in Ministry of Agriculture of the People's Republic of China: Fishery Yearbook, Beijing, China, 2013. ( in Chinese)

[2] Ministry of Enviromental Protection of the People's Republid of China: Pollution prevention and control technology policy for aquaculture (Opinion Soliciting Draft),2013. ( in Chinese)

[3] R. H. Bosma and M.C.J. Verdegem: Sustainable aquaculture in ponds: Principles, practices and limits. Livestock Sci.Vol. 139 (2011), p. 58-68. 
[4] M.F. Schwartz, and C.E. Boyd: Constructed wetlands for treatment of channel catfish pond effluents. Prog.Fish.Cult. Vol. 57(1995), p.255-266

[5] S.Y. Zhang, G. Li, H.B.Wu, X.G. Liu, Y.H. Yao, L. Tao, and H. Liu: An integrated recirculating aquaculture system (RAS) for land-based fish farming: the effects on water quality and fish production.Aquacult Eng.Vol.45(2011), p. 93-102.

[6] S.R.Ghate, G.J. Burtle, G.Vellidis, and G.L. Newton: Effectiveness of grass strips to filter catfish (Ictalurus punctatus) pond effluent. Aquacult. Eng. Vol.16 (1997), p.149-159.

[7] G. Li, J.Q. Zhu, S.Y. Zhang, L. Tao, X.L. Li, J.H. Song, and C.X. Zhang: Purification performance and production of a re-circulating pond aquaculture system based on paddy field. Int.J. Food Sci. Tech. Vol.4(2012), p. 383-388.

[8] P.J. Kouka, and C.R. Engle: Economic implications of treating effluents from catfish production. Aquacult. Eng. Vol.15 (1996), p.273-290.

[9] State EPA of China: Monitoring and Determination Methods for Water and Wastewater, 4th ed.(China Environmental Science Press, Beijing,China,2001). ( in Chinese)

[10] J. L. Garland : Analysis and interpretation of community-level physiological profiles in microbial ecology. FEMS Microbiol. Ecol. Vol.24(1997), p.289-300.

[12] M.H. Hu, J.H.Yuan, and X.E.Yang: Eutrophication purification and resource utilization by aquatic vegetables . J. Lake Sci.Vol.22(2010), p.416-420 (in Chinese)

[13] W. X. Li, and Z. J. Li: In situ nutrient removal from aquaculture wastewater by aquatic vegetable Ipomoea aquatica on floating beds. Water Sci. Technol. Vol.59(2009), p.1937-1943. ( in Chinese)

[14] X.C. Zhu: Study on an effect of sewage purification by artificial wetland and comprehensive evaluation. Agricultural University of Hebei Province, master's thesis,2012. ( in Chinese)

[15] H.T. Shen, G.S. Shan, M.C. Gu, M. Yang, and X.Q.Shen: Benefit of fish-lotus symbiosis ecological project. Rural Eco-Environ. Vol.17 (2001), p.17-20. (in Chinese)

[16] Y.Yang, C.K. Lin and J.S. Diana: Recycling pond mud nutrients in integrated lotus-fish culture. Aquaculture Vol. 212 (2002), p.217-230. 